\title{
Biofilm Formation in Reverse Osmosis Water at Hemodialysis Units in Two Hospitals Bandung
}

\author{
Aswin Yeoh Kit Shawn, ${ }^{1}$ Sunarjati Sudigdoadi, ${ }^{2}$ Diah Dhianawaty ${ }^{2}$ \\ ${ }^{1}$ Faculty of Medicine Universitas Padjadjaran Bandung, Indonesia, \\ ${ }^{2}$ Departement of Biomedical Sciences Faculty of Medicine Universitas Padjadjaran, Indonesia
}

\section{Abstract}

Background: Bacteria in aquatic environments do not usually live as a single free-swimming microscopic cell, but rather as communities of microorganisms that are attached to a surface in the form of biofilm. Biofilm is a major cause of concern to the medical world, as it protects the bacteria from a harsh environment, the host immune system, antimicrobial therapy, and even disinfectant. The aim of this study was to determine which genus or species of bacteria in reverse osmosis (R0) water was able to form a biofilm.

Methods: Water samples were taken from RO water of water treatment in hemodialysis (HD) centers at two hospitals in Bandung; at each point of the water treatment plant, bacteria were cultured. Any growth of bacteria was tested with a tube method to determine the formation of biofilm.

Results: Micrococcus luteus, Citrobacter diversus, Enterobacter aerogenes, Pseudomonas sp., Serratia sp., Acinetobacter sp. were able to form biofilm while Klebsiella pneumoniae and Staphylococcus saprophyticus were not.

Conclusions: Most bacteria isolated from RO water can form a biofilm, and a few are not. This study is successfully to check the possibility of biofilm formation of RO water, therefore, disinfecting RO water regularly is important and highly encouraged.

Keywords: Bacteria, biofilm formation, hemodialysis, reverse osmosis

\section{Introduction}

Reverse osmosis (RO) membranes and all pipes in the water treatment and inlet lines to the dialysis machine must be periodically disinfected to prevent the development of biofilms. ${ }^{1}$ Bacteria in natural aquatic environments do not usually live as a single free-swimming microscopic cell, but rather as communities of microorganisms that are attached to a surface known as biofilm. ${ }^{2}$ Once these biofilms are formed, they are resistant to disinfectant. ${ }^{3}$ Due to ineffectiveness of the disinfectant to remove the biofilm, the colonies of bacteria continue to proliferate and release endotoxins and bacterial fragments into the water. Formation of biofilm enables the bacteria to survive the harsh environment, the host immune system, antimicrobial therapy and disinfectant. ${ }^{3-5}$ Pseudomonas sp.,
Acinetobacter $s p$. and Serratia sp. are among the known biofilm formers. ${ }^{4,6,7}$

Continuous prolonged exposure to endotoxin will cause chronic inflammation in the hemodialysis patient.Chronicinflammation has been known to cause protein wasting, increased insulin resistance and promote atherosclerosis. ${ }^{8}$ Due to the implication of preserved biofilms in the hemodialysis unit, this study aimed to determine which genus or species of bacteria in RO water was able to form a biofilm.

\section{Methods}

This study was performed using a descriptive laboratory study design where RO water samples were taken from two hospitals in Bandung and transported in the icebox to maintain the temperature to the microbiology

Correspondence: Aswin Yeoh Kit Shawn, Faculty of Medicine, Universitas Padjadjaran, Jalan Raya Bandung-Sumedang Km. 21, Jatinangor, Sumedang, Indonesia Email: aswinyeoh@hotmail.com 
laboratory in the Faculty of Medicine Universitas Padjadjaran. The water samples were then processed immediately to ensure the viability of the bacteria. The identification of the bacteria genus found in RO water was examined in a separate experiment. The experiment was conducted from September to November 2014.

After the identification of the genus of bacteria, the bacteria were assessed for biofilm formation. The method to detect the formation of biofilm by the bacteria was conducted by tube method as described elsewhere. ${ }^{9}$ The tube method was a qualitative method with the usage of simple equipment to assess biofilm formation by adhesion of biofilm to the wall of the tube. ${ }^{9,10}$

The media used was trypticase soy broth (TSB) containing 1\% glucose and the reagents were consisting of deionized water or distilled water, phosphate-buffered saline at $\mathrm{pH}$ 7.3, $0.1 \%$ crystal violet with identified bacterial genus from RO water. In brief, the volume of $10 \mathrm{~mL}$ TSB was poured into test tubes and autoclaved for sterilization. A loopful of desired bacteria was transferred to the prepared TSB using an aseptic technique. The test tubes were incubated for 18 to 24 hours at $37^{\circ} \mathrm{C}$ in an incubator. The tubes were decanted and washed three times with phosphate-buffered saline ( $\mathrm{pH}$ 7.3) to remove planktonic cells. The tubes were then airdried up to 10 minutes. Next, the tubes were stained with $0.1 \%$ crystal violet and left for 30 minutes at room temperature. The tubes were then washed two times with deionized water or distilled water to remove the excess stain. The tubes were inverted and allowed to air dry. The formation of a ring at the liquid interface was not considered a positive result. A positive result for biofilm formation was observed when a visible film stained by crystal violet lines the wall and the bottom of the tube. This experiment was repeated 3 times to ensure valid results. Three sets of tubes containing TSB inoculated respectively with

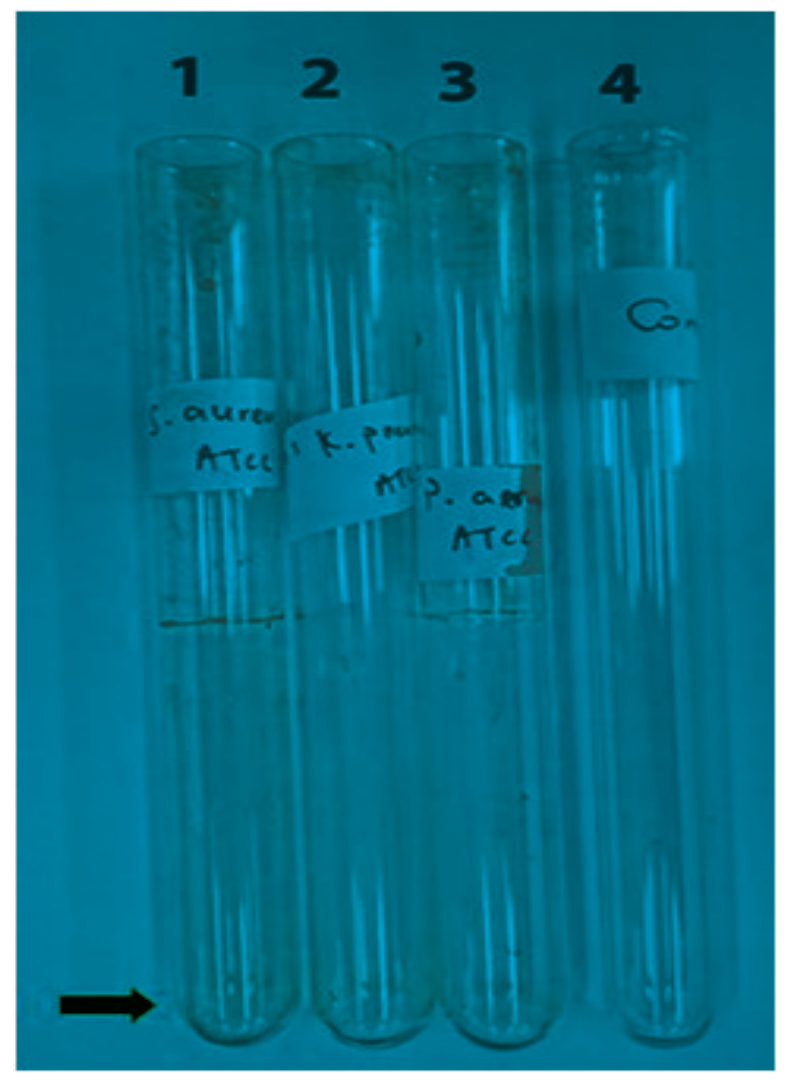

Figure 1 Positive Control Tubes

Note: tube 1 - Staphylococcus aureus ATCC 25923; tube 2 -Klebsiella pneumoniae ATCC 700603; tube 3 - Pseudomonas aeruginosa ATCC 27853. Tube 4 as a negative control. The red arrow as the indicator of an example of biofilm formation. 
Table 1 Genus or Species of Bacteria with the Ability to Form Biofilm from RO Water in Two Hospitals in Bandung

\begin{tabular}{lcc}
\hline \multicolumn{1}{c}{ Bacteria Genus/Species } & Number of isolates & $\begin{array}{c}\text { Number of isolates able to } \\
\text { form biofilm }\end{array}$ \\
\hline Micrococcus luteus & 10 & 10 \\
Pseudomonas sp. & 6 & 6 \\
Acinetobacter sp. & 5 & 5 \\
Bacillus sp. & 5 & 5 \\
Serratia sp. & 3 & 3 \\
Yersinia pseudotuberculosis & 3 & 3 \\
Enterobacter aerogenes & 2 & 2 \\
Citrobacter diversus & 2 & 2 \\
Klebsiella pneumoniae & 2 & - \\
Moraxella sp. & 1 & 1 \\
Staphylococcus epidermidis & 1 & - \\
Staphylococcus saprophyticus & 1 & 38 \\
Total & 41 & \\
\hline
\end{tabular}

Staphylococcus aureus ATCC 25923, Klebsiella pneumoniae ATCC 700603 and Pseudomonas aeruginosa ATCC 27853 were used as positive controls for biofilm formation and a tube containing TSB without any inoculation was used as the negative control (Figure 1).

\section{Results}

Our study showed that various genus or species of bacteria could form biofilm as shown in Table 1. Micrococcus luteus, Citrobacter diversus, Enterobacter aerogenes, Pseudomonas $s p$., Serratia sp., Acinetobacter sp. were able to form biofilm; while Klebsiella pneumoniae and Staphylococcus saprophyticus were not.

\section{Discussion}

Our study result has shown that the majority of the bacteria isolated from $\mathrm{RO}$ water are able to form a biofilm, similar to various studies. . $^{6,7,12-17}$ Enterobacter aerogenes have been known to have biofilm formation of regulatory protein BssR which might contribute to the formation of biofilm. ${ }^{18}$ The exceptions are Klebsiella pneumoniae (K. pneumoniae) and Staphylococcussaprophyticus(S. saprophyticus) that cannot form biofilm in our study, that is also confirmed in other studies. ${ }^{19,20}$

Biofilm formation needs close attention in hemodialysis units. Biofilm can protect bacteria from disinfectant, ${ }^{3}$ and biofilm thus can decrease the effectiveness of the disinfectant. Therefore, the colonies of bacteria can continue to proliferate and can release endotoxins or bacterial fragments into the water. Continuous prolonged exposure to endotoxin or bacterial fragments have been known to cause protein wasting, increased insulin resistance and promote atherosclerosis in hemodialysis patients. ${ }^{8}$

As this study requires the observation of crystal violet colour as an indicator for biofilm formation, this test tube test can be easily performed in simple laboratories. This research is limited by human eyesight and hence, the result is subjective. Also, to confirm that there is biofilm former, this research should be tested against other methods for assessing biofilm formation such as tissue culture plate. More advanced research is needed to further identify the types of bacteria with the ability to form biofilm in RO water. Effective disinfectant can be deployed before any formation of biofilm occurred. To identifying the types of bacteria, different types of disinfectants should be explored for the effective elimination of biofilm.

To conclude, the majority of bacteria isolated from RO water are able to form a biofilm, for examples Micrococcus luteus, Citrobacter diversus, Enterobacter aerogenes, 
Pseudomonas sp., Serratia sp., Acinetobacter sp., and only a few of bacteria which are not able to form a biofilm, such as Klebsiella pneumoniae and Staphylococcus saprophyticus. This study has shown that it is important to disinfect RO water regularly. Further studies are needed to identify potential agents able to destroy biofilms.

\section{References}

1. Glorieux G, Neirynck N, Veys N, Vanholder R. Dialysis water and fluid purity: more than endotoxin. Nephrol Dial Transplant. 2012;27(11):4010-21.

2. Petri WA Jr., Mann BJ, Huston CD. Microbial adherence. In: Mandell GL, Bennett JE, Dolin R, editors. Mandell, Douglas, and Bennett's Principles and practice of infectious diseases. $7^{\text {th }}$ ed. Philadelphia: Churchill Livingstone Elsevier; 2010. p. 22.

3. Bridier A, Briandet R, Thomas V, DuboisBrissonnet F. Resistance of bacterial biofilms to disinfectants: a review. Biofouling. 2011;27(9):1017-32.

4. Espinal P, Martí S, Vila J. Effect of biofilm formation on the survival of Acinetobacter baumannii on dry surfaces. J Hosp Infect. 2012;80(1):56-60.

5. Flemming HC, Wingender J. The biofilm matrix. Nat Rev Microbiol. 2010;8(9):62333.

6. de Kievit TR. Quorum sensing in Pseudomonas aeruginosa biofilms. Environ Microbiol. 2009;11(2):279-88.

7. Morohoshi T, Shiono T, Takidouchi K, Kato $\mathrm{M}$, Kato N, Kato J, et al. Inhibition of Quorum sensing in Serratia marcescens AS-1 by synthetic analogs of $\mathrm{N}$-Acylhomoserine lactone. Appl Environ Microbiol. 2007;73(20):6339-44.

8. Carrero JJ, Avesani CM, Mahmut IY, Bengt L, Stenvinkel P. Low-grade persistent inflammation and immune dysfunction in Uremia. In: Henrich WL, editor. Principles and practice of dialysis. 4th ed. Philadelphia: Wolters Kluwer Health/ Lippincott Williams \& Wilkins; 2009. p. 385.

9. Hirshfield IN, Barua S, Basu P. Overview of biofilms and some key methods for their study. In: Goldman E, Green LH, editors. Practical handbook of microbiology. 2nd ed. Florida: Taylor \& Francis; 2008. p. 679.

10. Oliveira A, Cunha MdL. Comparison of methods for the detection of biofilm production in coagulase- negative staphylococci. BMC Res Notes. 2010;3(1):260.

11. Ira P, Sujatha S, Chandra PS. Virulence factors in clinical and commensal isolates of Enterococcus species. Indian J Pathol Microbiol. 2013;56(1):24-30.

12. Newman JA, Rodrigues C, Lewis RJ. Molecular basis of the activity of SinR, the master regulator of biofilm formation in Bacillus subtilis. J Biol Chem. 2013;288(15):10766-78.

13. Matsuura K, Asano Y, Yamada A, Naruse K. Detection of Micrococcus Luteus biofilm formation in microfluidic environments by $\mathrm{pH}$ measurement using an ion-sensitive field-effect transistor. Sensors (Basel). 2013;13(2):2484-93.

14. Bai X, Wu F, Zhou B, Zhi X. Biofilm bacterial communities and abundance in a full-scale drinking water distribution system in Shanghai. J Water Health. 2010;8(3):593600.

15. Prieto C, Serra DO, Martina P, Jacobs M, Bosch A, Yantorno OM. Evaluation of biofilm-forming capacity of Moraxella bovis, the primary causative agent of infectious bovine keratoconjunctivitis. Vet Microbiol. 2013;166(3-4):504-15.

16. Fey PD, Olson ME. Current concepts in biofilm formation of Staphylococcus epidermidis. Future Microbiol. 2010;5(6):917-33.

17. Sun YC, Koumoutsi A, Darby C. The response regulator PhoP negatively regulates Yersinia pseudotuberculosis and Yersinia pestis biofilms. FEMS Microbiol Lett. 2009;290(1):85-90.

18. National Center for Biotechnology Information. Biofilm formation regulatory protein BssR [Enterobacter aerogenes KCTC 2190]. Maryland: National Center For Biotechnology Information, U.S. National Library of Medicine; 2014. [cited 2014 November 22] Available from: http:// www.ncbi.nlm.nih.gov/gene/10793176.

19. Maldonado NC, de Ruiz CS, Cecilia M, Nader-Macias ME. A simple technique to detect Klebsiella biofilm-forming-strains. Inhibitory potential of Lactobacillus fermentum CRL 1058 whole cells and products. Commun Curr Res Educ Top Trends Appl Microbiol. 2007;1:52-9.

20. Gundogan N, Ataol O. Biofilm, protease and lipase properties and antibiotic resistance profiles of staphylococci isolated from various foods. Afr J Microbiol Res. 2013;7(28):3582-8. 